\title{
"Mobile internet is worse than the internet; it can destroy our community": Old Order Amish and Ultra-Orthodox Jewish women's responses to cellphone and smartphone use
}

\section{Rivka Neriya-Ben Shahar}

To cite this article: Rivka Neriya-Ben Shahar (2019): "Mobile internet is worse than the internet; it can destroy our community": Old Order Amish and Ultra-Orthodox Jewish women's responses to cellphone and smartphone use, The Information Society

To link to this article: https://doi.org/10.1080/01972243.2019.1685037

\section{Published online: 25 Nov 2019.}

Submit your article to this journal ¿

\section{Q View related articles $\asymp$}

View Crossmark data $\asymp$ 


\title{
"Mobile internet is worse than the internet; it can destroy our community": Old Order Amish and Ultra-Orthodox Jewish women's responses to cellphone and smartphone use
}

\author{
Rivka Neriya-Ben Shahar \\ School of Communication, Sapir Academic College, Hof Ashkelon, Israel
}

\begin{abstract}
In this article I explore use patterns and perceptions of cellphone and smartphone use among Old Order Amish and Ultra-Orthodox Jewish women with participant observations, interviews, and a survey. My findings show that although they differ in their cellphone use (the Amish mostly do not use them and the Ultra-Orthodox only use those deemed to be "kosher"), they concur in their nonuse of smartphones - they see the smartphone as impure. Both view smartphones as undermining social relations and community by distracting users away from friends and family.
\end{abstract}

\author{
ARTICLE HISTORY \\ Received 19 July 2018 \\ Accepted 26 September 2019 \\ KEYWORDS \\ Apparatgeist; attachment; \\ cellphone; context collapse; \\ nonuse; old order Amish; \\ separation individuation; \\ smartphone; ultra- \\ orthodox; women
}

\section{Introduction}

Fanny, an Old Order Amish woman, wanted to call her family when we were out shopping together. "Let's find an Amish house on the road, and I'll call from their shared phone," she said. I told her that I had a cellphone, and that she could call from where we were. She deliberated, and I reassured her, saying, that it was not a smartphone, just a cellphone. She made her call, handling the cellphone like a weapon, carefully and from a safe distance. “Actually, I don't know the difference between cellphones and smartphones, I had just heard that smartphones are misleading and impure, so I decided never to use one in my life." This short interchange made me ponder on how much time, if any, I had devoted to thinking about the quick transition I had made from cellphone to smartphone. Since most smartphone users use them to continually access the internet, how deeply, if ever, do people think about the decisions and choices they make about which device to use and why, where and how often, and for what purpose?

To our understanding of use and nonuse of smartphones, I compare the perceptions and mobile use patterns of Old Order Amish and Ultra-Orthodox women, drawing on participant observations, interviews, and a survey. This study benefits from my being a scholar who is both in and outside a religious community. As an observant Jewish woman, raised within the Israeli National-Ultra-Orthodox community, with many Ultra-Orthodox relatives and friends, I had the chance to conduct multiple studies among the Ultra-Orthodox community. In addition, I have spent a great deal of time researching the Amish. A former social worker and now a media scholar, I combine psychological and media theories in my attempts to derive important and meaningful insights about the contemporary relationships between people and their smartphones.

Following an exposition of the main theories that guided my research, I present case studies of the Old Order Amish of rural Pennsylvania (hereafter: Amish) and the Ashkenazi Ultra-Orthodox Jews in Israel (hereafter: Ultra-Orthodox). They provide descriptions of their relationships with communication and media technologies - specifically, landlines, cellphones, and smartphones. They are followed by sections on methodology, findings, and conclusions.

\section{Theories from communications and developmental psychology}

I draw on one theory from communications Apparatgeist theory - and another from development psychology - separation-individuation theory - to 
explore the relationship Amish and Ultra-Orthodox users develop with their devices. I also draw another theory from communications - context collapse - to understand the relationship between context and their use of their devices.

Communications scholars Katz and Aakhus (2004) define Apparatgeist as: "the spirit of the machine that influences both the design of the technological device as well as the initial and subsequent significance accorded them by users, non-users and anti-users" (Katz and Aakhus 2004, 305). They talk of the "perpetual contact" engendered by mobile technologies between the individual and others and how it erodes the boundaries between the private and the public, generating "consistent strain to manage competing needs for connection and autonomy and the various boundaries people construct to manage the social world" (Katz and Aakhus 2004, 315-316). As Katz and Aakhus note, everybody is impacted - users, nonusers, and anti-users. Among the users of mobiles, especially heavy users, we see an intensifying relationship of attachment between people and their smartphones (Ahn and Jung 2016; Hoffner, Lee, and Park 2016; Tojib, Tojib, Tsarenko, and Sembada 2015). ${ }^{1}$ On the other hand, the nonusers, who are unable to afford connectivity, suffer disadvantages of being on the wrong side of the digital divide (Büchi, Just, and Latzer 2016; van Deursen and van Dijk 2014; van Deursen and van Dijk 2015; Hargittai 2004; Hargittai and Walejko 2008; Wyatt, Henwood, Hart, and Smith 2005). ${ }^{2}$ The anti-users deliberately choose not to use mobiles, even though they could afford them. They are understudied and are the focus on this present study.

In developmental psychology, attachment theory focuses on the system of behaviors that develops between infants and their caregivers through interactional strategies (Bowlby 1969, 1979). More specifically, separation-individuation theory charts the passage of normal infants from a non-boundaried autistic phase, through a symbiotic phase, to that of separation-individuation (Mahler 1972). When successful, this process leads to the infant ending his/her dependence on his/her caregiver, and creating an autonomous relatedness and flexible individuality (Mahler and McDevitt 1982). In effect, the infant starts developing a separation between "I" and "not-I" (e.g., infant's own thumb and a teddy bear) and becomes a toddler. For some children, the process can be facilitated with the presence of a "transitional object" such as a "corner of blanket ... which becomes vitally important to the infant for use ... [as] a defense against anxiety" (Winnicott 1953, 90). In this article we will see that by replacing the "caregiver" with the "smartphone" we can explore human-smartphone as a developmental process. Unfortunately, in this case the progression is in the wrong direction, from independent individuals, who were previously able to walk down a street and interact with others in person, to anxious creatures, attached, and almost merged with a new transitional object made of metal and plastic.

Nowadays relationship between a person and his or her smartphone is not merely attachment, but an enmeshment. Apparatgeist theory broadens our perspective smartphones as a transitional object to how it is becoming part of the body and soul of the user. People use smartphones while eating, going to the restroom, in the middle of the night, and feel stressed without it (Lookout Inc. 2012; Hoffner, Lee, and Park 2016).

In communications, Meyrowitz (1985) observed that electronic media were eroding the boundary between private and public spheres, with profound implications for social norms and expectations. $\mathrm{He}$ used an analogy from architecture to explain: "imagine that many of the walls that separate rooms, offices, and houses in our society were suddenly moved or removed and that many once distinct situations were suddenly combined" (6). In such a circumstance, while we will still have private and public selves, they would be greatly changed, and also how we present ourselves in different social situations, as our ability to segregate interactions will be greatly reduced. He called this phenomenon "context collapse." Relating context collapse to Goffman's (1956) social action theory, Meyrowitz notes that while context helps people to appropriately stage their performance and manage their identity on the backstage and onstage areas, "electronic media have increasingly encroached on the situations that take place in physically defined settings ... undermined the traditional relationship between physical setting and social situation ... created new situations and destroyed old ones' (7). Meyrowitz's theorization has helped scholars to explore changes in our mediated and face-to-face relationships (e.g., Boyd 2002, 2008, 2010, 2011; Ling 2012; Turkle 2008).

\section{The case studies}

I focus on two religious communities, both of which navigate the influences of the outside world and manage complex relationships with technologies, the Old Order Amish of rural Pennsylvania and the Ashkenazi 
Ultra-Orthodox Jews in Israel. Though many studies have considered the historical and sociological aspects of each of these communities, comparative work is sparse (Neuberger 2011; Spinner 1994).

The ways of life of both communities refer back to their European historical origins (Neuberger and Tamam 2014), but today the Ultra-Orthodox are an intellectual "society of scholars" whose members' lives are based on textual interpretations (Friedman 1991), whereas the Amish are a society of villagers and laborers whose members' lives are based on agriculture and small businesses. The two are similar primarily in their strict adherence to required religious behaviors and the strictures of their leaders. The Amish are an ethnocultural religious community borne of the Anabaptist movement, tradition, and values. The religious and social lives of the Amish are dictated by the Ordnung, a set of rules emphasizing humility, simplicity, obedience (Hostetler 1993; Kraybill 1989); and a deep commitment to Gelassenheit, "the idea of yielding fully to God's will and forsaking all selfishness" (Kraybill, JohnsonWeiner, and Nolt 2013, 65). Likewise, the religious and social life of the Ultra-Orthodox is bound by stringent interpretation of Halakha, Jewish religious law, commitment to the study of Torah, and unquestioning faith in rabbinic authority (El-Or 1994; Friedman 1991, 1993).

Both communities have deeply religious modes of worship and ritual, but very different practices. UltraOrthodox men pray in the synagogue at three set times daily, while the women are considered exempt from this commandment. The Amish family says short prayers twice daily, and the entire family participates in a long prayer service at their church every other Sunday. While the members of both communities frequently ask themselves "what does God ask of me" - a question I often ask myself - the Amish response is typically "the plain, simple way of life and hard labor," while the Ultra-Orthodox response is typically "intensive learning of Torah and Halakha, and stringent practice of the Halakhic rules, for example: kashrut (dietary laws)."

Both communities are minority groups: The Amish number close to 331,000 , less than $0.001 \%$ of the population of the United States (Young Center 2019), while the Ultra-Orthodox constitute about 1,000,033 $12 \%$ of Israel's population (Cahaner, Malach and Choshen 2017). Both have complex relationships with their governments, and separate educational and legal systems. Both live among secular, modern, Western, populations and have values that differ from those surrounding them (Almond, Appelby, and Sivan 2003; Douglas 1966). Both wear distinctive clothing. Both have their own languages. The Amish speak Pennsylvania Dutch and some groups of UltraOrthodox speak Yiddish. However, they are also versed in the languages of other populations around them, English and Hebrew, respectively.

The Amish are located in rural areas of North America and Canada. The largest Amish populations are in Pennsylvania, Ohio and Indiana. The Israeli Ultra-Orthodox communities are located primarily in urban areas, particularly in Jerusalem and Bnei Brak (near Tel-Aviv) though there are also Ultra-Orthodox communities located in the peripheries of Israel. The Amish usually live among the "English" in rural areas, in contrast to the self-imposed isolation of the UltraOrthodox, who choose to live in separate neighborhoods, in the large cities as well as the periphery. ${ }^{3}$ Both perceive the societies surrounding them to be ideologically secular, qualities that run contrary to their religious values. Accordingly, both communities practice intra-communal marriage, and adopt a similar range of strategies involving dress, language, place of residence, and economy to set themselves apart from those living around them (Friedman 1991; Kraybill, Johnson-Weiner, and Nolt 2013). Nevertheless, as recent studies point out, both communities have extensive personal, social, economic, and cultural ties with other populations around them (Cahaner and Zicherman 2012; Caplan and Stadler 2012; Hurst and McConnell 2010; Kraybill, JohnsonWeiner, and Nolt 2013; Sivan and Caplan 2003), many of which are forged by women (JohnsonWeiner 2001; Neriya-Ben Shahar 2008, 2009).

\section{Old Order Amish and Ultra-Orthodox women}

The literature on Ultra-Orthodox (e.g., Davidman 1991; El-Or 1994; Fader 2013; Neriya-Ben Shahar 2008, 2012) and Amish women (e.g., Graybill 2009; Johnson-Weiner 2001; Jolly 2007, 2014; Schmidt and Reschly 2000; Schmidt, Zimmerman-Umble, and Reschly 2002; Van Ness 1995) informs us that on average, the women in both communities are mothers of seven children, responsible for the home, children's education, family needs, and community support. The differences between the two groups lie primarily in education and work patterns. Amish women (like Amish men), have only 8 years of schooling, while Ultra-Orthodox women have an average of 14. Amish women usually stay at home, some of them running their own or partnering with their husbands in a 
small family business, mostly at or close to home, as compared to Ultra-orthodox women who often work full time out of the house, while their husbands study Torah. The women of both communities have multiple relationships with groups outside, especially in terms of consumption and health, but because of their jobs, Amish businesswomen and Ultra-Orthodox women who work outside the home navigate more complex and intensive relationships with other populations around them.

Although the Amish women are housewives and the Ultra-Orthodox women are mostly teachers or high-tech workers, the primary similarity between them lies in their full commitment to the religious and community values and practices. The very basic daily act of shopping is illustrative of this commitment. The women of both communities buy huge quantities of food for a family of on average 9 people, with some extra for guests or people suffering from illness in the community. Both would be thinking about multiple things while shopping: price, since typically neither has a high income, and how this food might help others, especially the needy. However, it is only the Ultra-Orthodox who are committed to the very complicated rules of kosher food, which, though a religious constraint, also provides a powerful symbol for attaining position within this community. Among the Ultra-Orthodox, the more strictly kosher one's practice, the more valued one is. It is a point of pride for people to say that they do not eat this or that food, because the level of the kosher is not the very highest. Limiting one self to "the most strictly" kosher food displays a deep commitment to the most stringent halakhic rules, which is of the highest value in this community (Friedman 1991). As we will see later, the notion of kosher, consumption in accordance with the strict halakhic rules, has now been extended to the use of cellphones and smartphones.

I had many opportunities to shop for clothes with women from each community. An Amish woman might invest a half hour in an Amish dry-goods store, deliberating between five versions of almost the same plain and simple black sweater, and then decide that she should buy the simplest, according to the most stringent rules. An Ultra-Orthodox mother could take her daughters to ten stores, until she finds the exact skirt with a specific length that is not too short, so as to be set apart from the secular community, and not too long, to differ from the Modern Orthodox community. For an outsider, these could be seen as a huge waste of time - contemporary people can buy basics such as these, according to their personal choices. But within these communities, these choices are a vital and symbolic display of their loyalty to the community and the rules, as well as to their personal relationships with God. These deliberations and choices multiply when Amish and Ultra-Orthodox people deal with issues of technology.

\section{Technology among Amish and Ultra-Orthodox}

Communication technology plays an important part in the creation of the boundaries in every community, as its deployment and use entails negotiations on power and authority (Marvin 1988). Further, politics, economics, and culture shape the development of technology and vice verse (Leonardi 2003, 2009; Pinch and Bijker 1984). These community-technology relationships are more complicated in religious societies (Stout 2001).

Communication technologies present a Faustian bargain to traditional communities (Ginsburg 1991). On the one hand, religious groups tend to see them as threats to core values of their communities. On the other hand, many religious groups use them to spread their faith (Campbell 2010, 2013, 2015). On the balance, if communication technologies might open the community to the secular world, they would be rejected, especially if they "encourage the cultivation of values and practices antithetical to the communities' prescribed religious life" (122).

Ostensibly, the Ultra-Orthodox generally make practical use of technology whereas the Amish reject innovation. The reality is actually far more complex in both communities. Each has intense discourses about different aspects of technology, as well as strong opposition to it, especially from the leadership. Daily use involves an intricate combination of acceptance, rejection, and adaptation (Ems 2015; Johnson-Weiner 2014). Both communities use a variety of technologies, employing processes of adaptation and appropriation. For example, I have seen a car battery utilized to run a food processor in an Amish home, and UltraOrthodox homes with large radio-tape-recorders with the radio button broken.

McLuhan's (1964) maxim "the medium is the message" is very pertinent for our present discussion. My observations show that the fear among the Amish is primarily of the medium; they embrace various modern engineering and other innovations that make farm work more efficient (Kraybill 1989; Kraybill, Johnson-Weiner, and Nolt 2013; Nolt 2016), while prohibiting the introduction into the home of new communication technologies such as television and 
radio. They mainly read newspapers and magazines targeted for "Plain people" - various groups of Amish and Mennonites, among others (Fishman 1987, 1988). In most Amish houses for example, we can find the journal "Family Life" and/or Amish correspondence newspapers such as "Die Botschaft" (Cooper 2006; Hurst and McConnell 2010). However, my observations show that they also allow the entry of some secular messages via print newspapers mostly picked up in local stores, such as the "Lancaster New Era Newspaper" or the "Pennysaver".

The Ultra-Orthodox, in contrast, mostly fear the message. They freely use technologies that do not offer content, such as cars and electricity, but have created a long line of limitations for technologies that do offer content. They bar the entry of mainstream media into their homes, irrespective of the technology involved, while simultaneously harnessing the most modern technologies to facilitate the consumption of their own community's content and also to block forbidden material (Caplan 2007; David and Baden 2018; Golan and Mishol-Shauli 2018). For example, the general Israeli newspapers are forbidden in most UltraOrthodox homes, and a reference to something from these papers could constitute a reason to expulsion of a child from school, as the other families fear the negative influence of a family that allows secular newspapers in their home. In many Ultra-Orthodox communities there is also a ban against UltraOrthodox magazines, because they are published by seemingly more liberal Ultra-Orthodox groups. There are schools where a child might be expelled for saying that he read something in Mishpacha magazine, because it includes discussions about the community's challenges, as well as photographs of girls under the age of three.

The relationships of these communities with the internet are far more complex than their relationships with newspapers and other traditional media. The internet, even filtered, is antithetical to the values of both communities, but since it is essential for the employment of many Ultra-Orthodox and Amish people, its limited use is permitted outside the home and primarily for business needs. The Ultra-Orthodox use patterns are higher and more varied than those of the Amish (Barzilai-Nahon and Barzilai 2005; Campbell 2010, 2015; Livio and Tenenboim Weinblatt 2007; Neriya-Ben Shahar 2017a).

Moving from general attitudes among the Amish and Ultra-Orthodox communities toward their specific use of and perceptions of various phones, we should note that both communities generally invest great thought and effort into determining what is permissible and what is not. For example, they both practice a complicated system of sorting appropriate clothing, as discussed earlier. Ultra-Orthodox Jews think many times daily what they are permitted or forbidden to eat, whether the food is under the strictest kosher supervision, what and when they themselves last ate (after eating meat they must wait six hours before they eat dairy), or which blessing should be said prior to and following the eating of everything. Similarly, the Amish and Ultra-Orthodox have complex sorting systems for determining which mobile phones are permissible and which are not. Is this device appropriate for our values? What do the leaders say about this specific device? What might be the consequences of a specific use, or general use? These are the questions they ask themselves, and in this study, we listen to their answers.

\section{From landline to smartphone}

The emergence of landline phones set off a big debate among the Amish and led to a schism in 1910, with one-fifth of the congregation leaving the Amish church (Zimmerman Umble 1992, 2003). The Amish see the telephone as "... an umbilical cord tied to a dangerous worldly influence” (Hostetler 1996, 349) that might break the social order. Today, many Amish communities compromise by keeping the phone outside their homes so that it cannot interrupt daily life. In contrast, the Ultra-Orthodox have accepted the landline phone, placing it centrally within the house in order to control conversations by family members.

The cellphone, however, created new challenges for both communities. It enables independence, which is in direct opposition to Amish culture (Nolt 2015). The Amish interviewees reported that cellphone prohibition is a major issue in preachers' sermons. Ultra-Orthodox leaders also oppose the cellphone, threatened by its small size and availability - both features reduce the possibilities for social control. Its threat lies in the fact that it "allows for readily available communications between individuals, a convenient tool for maintaining interpersonal relationships" (Rosenberg and Rashi 2015, 161). It enables hidden connections between men and women, either within the community, and/or with outsiders. Other concerns relate to inappropriate and immodest content, as well as wasting of precious time (Campbell 2010; Cohen, Lemish, and Schejter 2008; Deutsch 2009).

Both communities have implemented modifications that enable their members, particularly business 
owners, to communicate with others through cellphones while following the communal rules. The Amish use clever technical solutions for appropriating the technology and bringing it in accord with their values, from "Plain computers" to "Plain phones" such as Black Box Phones (Ems 2015), neither of which have internet access. Some Ultra-Orthodox leaders, in tandem with several communication companies, developed a kosher cellphone (Campbell 2010; Rashi 2013; Rosenberg and Rashi 2015), or what Cohen, Lemish, and Schejter (2008) call "a slim phone." Technically, a kosher cellphone can only receive and make phone calls, without the ability to text, send pictures, video, or any sort of internet surfing.

The kosher cellphone device itself and the call plan are typically less expensive than other cellphones, and significantly cheaper than smartphones. The companies also offer a "kosher package" of services, that blocks phone calls on Saturdays, sometimes for lower prices than the packages offered to other communities. Companies offer such products and services not because of their corporate values but because of the growing demand for phone plans in the UltraOrthodox community in Israel. Here too a comparison to kosher food is apt, as many companies began to ask (and pay) for the implementation of kosher standards and supervision, because they recognized the market growth potential of the Ultra-Orthodox community and saw it as a reason to cater to its special needs. On the recommendation of the religious committee, the phone numbers on these plans also include a special identifying prefix of three numbers, which enables the receiver to identify the religious identity of the caller, whether he/she is "one of us", and to sanction any noncompliance. These phones also have a kosher mark, which, similar to kosher symbols on food (Blondheim and Rosenberg 2016; Campbell 2007, 2010; Rosenberg, Blondhiem, and Katz 2016). Incidentally, the Ultra-Orthodox also use kosher for strictly modest dressing (a topic for another study). Similar to the apropos name "Plain phone" as appropriate for "plain people", "kosher phone" has resonance for the UltraOrthodox community.

The advent of smartphone has initiated new discussions within religious communities, and while some of them have modified it for their needs (Campbell and La Pastina 2010), both the Amish and the UltraOrthodox try to keep it out of bounds because it poses a unique threat - the internet in one's pocket. However, the reality is that both communities distinguish between use and ownership. Use enables members to use someone else's smartphone when needed.

The reality is that in practice it is difficult to police use of smartphones. For instance, we are seeing a new phenomenon of the hidden phone - Ultra-Orthodox person with a visible kosher phone and a hidden smartphone (Campbell 2010, Deutsch 2009). In recent years a new device has appeared, a kosher smartphone, with kosher apps and a symbol indicating kosher supervision, which enables not only calling and receiving and limited apps such as GPS, calendar, email and filtered internet to allow access for specific business needs. The procedure for acquiring a kosher smartphone entails coming before a rabbinic committee to prove that the smartphone is necessary for one's job, and fully accepting the committee's jurisdiction and control over the filtered apps and internet surfing.

Livingstone (1992) argued that household technologies can play multiple roles, based on necessity, functionality, control, and privacy. By observing these roles, we see that both communities, with their leaders' involvement, create a complex system of assessment and evaluation, which takes into account the real functions and necessities of different members for technological devices (Ems 2015). However, these communities use different sanctions to control the community, which indicates that the values of the society and community have a higher priority than the privacy of the individual, as I will discuss further below. These complexities, as demonstrated by this review of the literature, lead to the following research questions:

Research Question 1 (RQ1): What are the use patterns of cellphones and smartphones among Amish and Ultra-Orthodox women?

Research Question 2 (RQ2): What are the perceptions of Amish and Ultra-Orthodox women regarding the use of cellphone and smartphones?

Research Question 3 (RQ3): What symbolic meanings do non-users among Amish and Ultra-Orthodox women attribute to these devices?

\section{Methodology}

During the years 2011-2019, I conducted multiple ethnographic participant observations of Amish and Ultra-Orthodox women's media use practices in a variety of contexts, and dozens of short ethnographic interviews. I also conducted a written survey 
comprised of both open qualitative and yes/no questions. Forty women of the Old Order Amish community in the Lancaster County, Pennsylvania, filled out the questionnaires (in English) during the spring and summer of 2012. Forty-two Israeli Ultra-Orthodox women $-67 \%$ (28) from Jerusalem Ultra-Orthodox community, largest one in Israel, and 33\% (14) from Zichron Yaakov, filled out the same translated questionnaires (in Hebrew) during the fall and spring of 2013.

The first drafts of the questionnaire included multiple-choice questions and items with Likert scale-based ratings. In previous studies (Neriya-Ben Shahar 2008; Neriya-Ben Shahar and Lev-On 2011; Lev-On and Neriya-Ben Shahar 2012), Ultra-Orthodox women had easily answered these types of questions. In contrast, the Amish women, who participated in the pretest (and also helped formulate the language), found it difficult to answer questions in such formats. Perhaps the reason is that Amish women, who typically had only eight years of schooling were less familiar with such question formats, while the Ultra-Orthodox women had on average 14 years of formal education. I therefore re-formulated all of the objective-type questions to either yes/no questions, or questions requiring articulated responses. I asked about the subjects' perceptions of and attitudes toward media, their knowledge of technologies, gender and usage, and women's supervision of media use by family members (Livingstone 1990, 1992). Therefore, the quantitative analysis is limited to simple data (percentages). The richer qualitative analysis is based on a grounded-theory approach (Strauss and Corbin 1990). Although the study itself covered various media, this article focuses only on responses relating to cellphone and smartphone use.

I hired assistants from within the communities to help recruit participants and administer the questionnaires, usually in the subjects' homes. In practice, I gave printed questionnaires to four Amish and three Ultra-Orthodox women, and asked them to distribute them to other women in their communities, as well as to try to reach women outside their close circles. Women who agreed to participate in the study were informed that the purpose of the study was to understand how they view and utilize media, and they signed an informed consent to participate. They were assured there were no correct or incorrect answers.

\section{Population and sample}

Participants were chosen from the women of Lancaster County's Old Order Amish and of Israel's
Lithuanian and Hassidic Ultra-Orthodox Jews. The Lancaster County's Amish population was 31,000 in 2012 (Kraybill, Johnson-Weiner, and Nolt 2013, 186) and 38,000 in 2018 (The Amish Population 2018). The Ultra-Orthodox population in Israel was 1,000,033 in 2017 (Cahaner, Malach, and Choshen 2017). The focus here is on "mainstream" sub-communities that are generally familiar with media technologies but choose to limit their use of them. While the scope of this study did not allow comparisons between stricter (Nebraska Amish/"Mea Shearim" Ultra-Orthodox) or more liberal (New Order Amish/ Modern Orthodox) sub-groups, such investigations would be valuable future follow-ups of this study.

The study used snowball sampling, which is particularly suited to closed communities (Lee 1993). Selection from groups with different demographic characteristics mitigated the internal homogeneity of each population. Because of the ongoing debate with regard to the definition of Amish and UltraOrthodox, I relied on the self-definition of the respondents (Friedman 2011; Pew Research Center 2013). Even though this snowball sample is based on only 82 participants (I paid all the research expenses out of pocket), I wanted to ensure that differences in their answers were the product of cultural differences and not demography. Therefore, the number of children and ages of the women who filled out the questionnaires were compared by an independent t-test. No significant differences were found between number of children $(t(68)=.15, p>.05)$ or the ages of the women in the two groups $(t(34.8)=1.32, p$ $>$.05).

\section{Challenges}

Cross-cultural research of media is particularly challenging (Livingstone 2003) specifically in Amish and Ultra-Orthodox communities (Adkins 2012; Kraybill 2008; Rier, Schwartzbaum, and Heller 2008). My experience with the Ultra-Orthodox community is informed by my personal biography: I was raised in a nationalist-Ultra-Orthodox family and have many ties to family members and friends in this population. My entry into the Amish community was via a personal connection I developed with an Amish family in Lancaster during my stay in the US as a Fulbright scholar. I resided on their farm for eleven separate one-to-three-week periods. I washed dishes and ran errands with my rental car, driving family members to shopping centers, church services, and youth groups, thereby establishing contacts with many people from 
various regions and deepening my understanding of the lives of the Amish.

With the Amish, our differences became a blessing. I worked in their garden on a hot Sunday to save the strawberries my host did not have time to pick before their holy Sabbath, while they helped me with the flashlight on my Sabbath (their Saturday). We shared the same table, with me eating kosher food, which they let me keep in a separate space in their refrigerator. Obviously, my modest religious garb, long sleeves and skirts, and hair covering were indicative of values we had in common. Discussions on the points of convergence and divergence of our faiths created a deep closeness and openness, which led to deep insights.

This challenge reflects the need to bridge the gulf between insiders and outsiders (Donovan 1990; Firth 1996), which in the case of religious communities boils down to whether one is able to understand and explain acts and beliefs of others (McCutcheon 2005). I used various suggested solutions. I follow Geertz's (1983) approach of "searching out and analyzing the symbolic forms - words, images, institutions, behaviors-in terms of which, in each place, people actually represented themselves to themselves and to one another" (56). He prefers the experience-near research - what the informant "might himself naturally and effortlessly use to define what he or his fellows see, feel, think, imagine, and so on, and which he would readily understand when similarly applied by others" (55). Conversely, in experience-distant research the ethnographer is guided by her research objectives. I also employ the reflexivity method for this study. I, following Said (1979), try not to separate between "they," the "primitive" religious women and "we," the "sophisticated" Western scholars, but instead, as McCutcheon (2005) suggests, be involved in appropriating the other's myths, practices, and experiences in my own autobiographical quest.

My personal conversations with the Amish women and experience with the Ultra-Orthodox community, led me to believe that the respondents would be concerned that they might be identified by their responses, asked questions offensive to them, my research assistants would appear in immodest dress, and participation in the research would take up too much time. The first concern was assuaged by assurances of complete anonymity; the numbered questionnaires contained no identifying information, as in Cooper (2006). The women's quotes are presented with typical, though fictional Amish or UltraOrthodox names. I was able to resolve the second concern by formulating the questionnaires with sensitivity to language and values. With regard to the third concern, since the research assistants in both groups belonged to the respective communities, their manner of dress and behavior were acceptable. As I mentioned above, as a religiously observant Jew, I dress in a manner that is appropriate for both groups. As to the fourth concern - I paid $\$ 10$ for the participants' time when the questionnaire was completed (payment for the research assistants and the participants were out of my own pocket).

\section{Findings}

\section{Use patterns}

The first research question was: What are the use patterns of cellphones and smartphones among Amish and Ultra-Orthodox women? The data shows that 5\% (2) of the Amish women, compared to 90\% (38) of the Ultra-Orthodox women, own a cellphone, 85\% (35 of the 38 were kosher models). To the question: "Have you ever used a mobile phone?" Sixty percent (26) of the Amish and all (100\%) of the UltraOrthodox answered "yes." No one in either group had a smartphone, and 92\% (37) of the Amish and 93\% (39) of the Ultra-Orthodox answered "no" to the question: "have you ever browsed the Internet on a mobile phone?" Tojib, Tojib, Tsarenko, and Sembada (2015) argued that the use or ownership of a smartphone expresses one's identity to others. I argue that the data indicate that these women express their high religious and cultural capital by limiting or not using these devices at all.

In my fieldwork, I had opportunities to see women from both communities use cellphones. Though their use can be similar to a landline phone, mobility can make a difference. The Amish women, deterred by the temptations of mobility, used it as a necessary convenience, returning it to its owner immediately following the conversation. Ultra-Orthodox women, however, were comfortable using a cellphone to make a phone call, due to its similarity to a landline phone. In fact, the small, handy kosher cellphone, such as the Nokia C2, enables only calling functions, alarm clock and calendar, with no internet connection, texts or any other function.

As I mentioned, the Amish woman to whom I loaned my phone held it with trepidation. The UltraOrthodox women, however, have personal connections with their kosher cellphones. They decorate them with colorful little beads and stickers, which for some serve as valuable reminders to refrain from 
gossip. This connection is also marked by constant physical contact with their device. At some UltraOrthodox weddings, I noted that the women mostly held their phones in their hands or kept them close, beside their plates or in the strollers. Many women held them while conversing standing up, some even circle-danced while holding them. I was surprised to encounter a decorated kosher phone in a woman's hand when I joined in one of the dances. I found it uncomfortable to dance this way, so I switched to another circle, only to have my hand touch another cellphone.

For deeper understanding of this observation, I should mention that members of the Ultra-Orthodox community keep very strict rules of separation between the genders. At events such as weddings, the hall is divided by a moveable wall, often built of wood, to create a physical separation between the genders. Sometimes there are spaces through which the women can watch the men dancing, though the men are not permitted to watch the women. At the ends of the wall there are informal meeting points, where married couples can talk briefly, especially to coordinate departure times. When I asked the women why they dance with their phones in hand, some said that they want to remain available to their husbands; others said that they are trying to stay available for their other children who were left at home; while still others, especially those with demanding jobs such as the community center's manager or nurses explained that they must stay "on call" for their workers or colleagues. I asked the women if the phones were silenced, and they said that they were not. But then, music at an Ultra-Orthodox wedding is usually so loud that the ring cannot be heard.

"I need to be connected to the world," Sari explained, "If my husband needs me from the other side of the hall, if the children need me, or if something is happening at my work". "Connected to the world?" I asked, and she laughed: "I don't mean to be connected to the world like the smartphone users! I don't have news, pictures, etc. It's just a technical issue of real communication, connection to the people who need me". Sari's distinction between connectivity with people who need her, and the entertainment aspects of the phone, will be discussed later. Nevertheless, whatever the reasons, the close interaction between Ultra-Orthodox women and their cellphones, though with limited content and applications, is in sharp contrast to the distance kept by Amish women from cellphones. I cannot even imagine an
Amish woman holding a cellphone during a wedding meal, even if she works for a business.

\section{Women's perceptions}

The second research question was: What are the perceptions of Amish and Ultra-Orthodox women regarding the use of cellphone and smartphones? The women's responses to questions about cellphone use were similar in both communities, in that they were straightforward and brief, though different in content. The Amish response was that owning a cellphone is not permitted, but when necessary someone else's cellphone may be used. Most of the Ultra-Orthodox, however, responded that since a kosher cellphone is just like a landline phone, it is permitted. Their responses regarding smartphones, however, were much longer and more complex. Since none of them have a smartphone, and almost all of the UltraOrthodox women wrote that they never used one, we can assume that their perceptions are based on their observations as "outsiders" of smartphone users alongside sermons and texts on the subject. Their responses can be divided into three aspects: (1) opposition to the content; (2) a time-wasting device; and (3) the smartphone threatens community values and the leaders' guidelines.

Opposition to the content: Mary, an Amish woman, said: "Too much junk with which to fill a mind"; and Anna wrote: "Misleading. So many things on it leading you to think about things that you don't want or need to know". The Ultra-Orthodox women, however, knew more about the content, and their answers have more details: "The smartphone is the most dangerous device, it includes newspapers, radio, television, and mail. It has impure content, everything is there, obscene pictures, connections with strangers on Facebook? 'Creating contacts' is totally adultery", wrote Sara; "It's [the smartphone] full of subjects we never have, gossip, paparazzi, immodesty, addictions, cruelty, obscenity. When one sees rotten things, one's soul, perspective, and actions are all affected," Bruria told me.

Waste of time: "The smartphone is a waste of time," answered many women. They referred to holy time - "It is misleading if spending too much time away from the Lord," wrote Lizzy; while Shifra suggested: "If you have time when you travel, you can always learn Torah." The women also addressed their family and community time, as Seidi explains: "It ruins our quality family time, and too much time spent with mobile devices takes away the feeling of a 
close-knit community." "Our life is hectic, it's a shame to waste time with smartphones instead of talking with your family," described Shira.

The smartphone threatens community values: To the question "Do you think that mobile Internet browsing is in keeping with Amish/Ultra-Orthodox values?" Ninety-seven percent (39) of the Amish and 98\% (41) of the Ultra-Orthodox answered "no." Susan explains: "our values are handed down from generation to generation $[\ldots]$ it interferes with those values", and Lavina wrote: "It's a great danger to our way of life and could be to our faith." "It is full of values and messages that contradict those which underlie the education of the Ultra-Orthodox community," said Yocheved. "It can destroy your spiritual world", explained Tehila. Women from both communities also explained the opposition of their leaders - "It's not supported by the church standards," wrote Naoma; while Beki-Lyn wrote: "our leaders, who are appointed over us, have decided it's something we don't want among our people." Devora wrote: "the Rabbis forbid it!" And Dina said simply: "I don't know what this is. I've just heard that the rabbis scream [...] so I understand that it must be awful." The women asked if the smartphone holders could even define themselves as community members. Ruda asked me painfully, "Are they [smartphone holders] really Christian? Are they really Amish?" "I know someone who has a non-kosher smartphone. She can't define herself as Ultra-Orthodox anymore," said Esther, and Rivka explained: "The smartphone destroys the inside of people. On the surface, the person looks Ultra-Orthodox, but on the inside, everything is spoiled." Regarding group sanctions, interviewees from both communities said that they would report and penalize smartphone holders.

These responses are in line with other studies on the how religious communities "negotiate" with media. Broadly, they resonate with Campbell's (2010) RSST (Religious-social shaping of technology) model, and, specifically, with Stout (2012), who observed that content, time, community values, and leaders' opposition are all common responses of respondents from religious communities, and Neriya-Ben Shahar (2017a, b), who reported similar findings in studies of attitudes of the Amish and the Ultra-Orthodox women toward internet and television. Nonusers of smartphone (Reisdorf and Groselj 2017) and users of cellphone who think that the cellphone is a "necessary evil" (Nafus and Tracy 2004) share the same negative feelings toward television and the internet.

\section{Symbolic meaning}

The third research question was: What symbolic meanings do nonusers among Amish and Ultra-Orthodox women attribute to these devices? Respondents indicated two levels of symbolic meaning.

\section{Symbolic meaning 1: Technology controls people}

Respondents felt that smartphone itself, regardless of content accessed, controls its user. "This device controls people", Lydia observed, after seeing smartphone users during our travels. The women felt that the smartphone creates negative changes. "Having all information at your fingertips is changing the way people communicate and act, it is much more an atmosphere of 'I need it now," Barbie explained. The Ultra-Orthodox women were more explicit: "It consumes everything, from soul to flesh," said Shulamit, and Liba wrote: "It is so sweeping, so addicting, it is just like drugs."

Some women tried to figure out the motivations of the technology creators and users: "they have used the miracles of technology to destroy humanity", wrote Tehila. Suzan looked at my smartphone and said:

Smartphones? We believe that technology is bad in a lot of ways, and the more there is, the worse it is [...] the more advanced it is, the more it tries to suck you in into a circle of having to have more and more things $[\ldots]$ it is controlled by sinful people.

While the Ultra-Orthodox women see the technology as miraculous but blame the users, the Amish woman perceive the creators of technology as sinful.

Intensive use, portability, availability, and accessibility: The participants observed from their perspectives, what Tojib, Tojib, Tsarenko, and Sembada (2015) call user-smartphone relationships: "I see how much the English use it. They call, text and show pictures all the time," Seidi told me. Some addressed the portability, as Fanny writes: "if you carry a smartphone you are surrounded by temptation." "The evil accompanies you everywhere, not leaving you for even a moment," (Hana). "Its availability causes great exposure to degeneration [... at least] a television wasn't portable," (Devora). The Ultra-Orthodox women had more experience than the Amish, and many of them reflected on the accessibility aspect. "Mobile internet is worse than the internet, because [...] the accessibility can destroy our education," wrote Tova. Giti explained: "The accessibility of the smartphone creates huge temptation. Our Sages said: 'Until the day you die, do not trust yourself.' Accessibility leads to less [external] control - people can hide their use." Hindi observed: "It's so simple, so easy, so accessible $[\ldots]$. No effort is 
necessary with such a small device that enables you to reach sites that Ultra-Orthodox people are not allowed to see and hear." Feigi said: "one can seclude oneself anywhere, with the device without any [external] control." Feigi uses a sensitive term lehityahed - which is a Hebrew halachik term for the prohibited, unsupervised, intimate situation of a man and woman alone, together. In effect, the smartphone has connotations of being inappropriately sexually threatening.

These women's responses resonate with the rich literature on gender and media technologies, focusing on attitudes, behaviors and uses toward media (e.g., Fiske 1986; Lim and Soon 2010; Morley 1992; Press 1991; Tacchi, Kitner and Crawford 2012) and gendered use of domestic technologies (Hobson 1981, 1990; Livingstone 1992; Morley 1998; Silverstone 1991; Silverstone, Hirsch, and Morley 2002). Addition of religion to the interplay between gender and media provides further insights (Hess 2013; Lovheim 2013 a, b, c). The literature includes specific studies about Ultra-Orthodox women and media are relatively rich (e.g., Davidman 1991; El-Or 1994; Fader 2013; Neriya-Ben Shahar 2008, 2012; Neriya-Ben Shahar and Lev-On 2011; Lev-On and Neriya-Ben Shahar 2012). However, I could not find even one specific study focused only on Amish women and media technologies.

\section{Symbolic meaning 2: Backward movement}

Comparative studies of Amish and Ultra-Orthodox women have shown that media technologies are fundamental challenges for both (Neriya-Ben Shahar $2017 \mathrm{a}, \mathrm{b})$. They use their agency to navigate the tension between their roles as change-agents and gatekeepers. Specifically, they cope with the internetrelated challenges through "nonuse, control, and limitations vis-à-vis the internet" which "constituted a valuable current in the cultural and religious markets of women from devout communities" (Neriya-Ben Shahar 2017a, 91). Their perceptions and attitudes show that in the case of the smartphone they use their agency in a different way - when they see the boundaries disputation, they choose the role of gatekeepers, and oppose the smartphone. This opposition is connected to their perceptions toward the systems connections, as I will show in this section.

Women from both communities thought that the smartphone could change the existing networks of connections and relationships. It creates a link to the outside world and prohibited content, and even more problematically, it can destroy the connections within families and communities. Here the women specifically used the terms connect or contact, as opposed to talking about content in general (covered in the preceding subsection).

Connection to the world: Mary wrote: "I think it's too easy to get in contact with worldly things" (italics added), and Lydia wrote: "It connects us too much to the world" (italics added). Rivka explained: "It's connected to information that is hurtful to your soul, offering options to connect with inappropriate people" (italics added). The women also referred to connections with self, family, and society being replaced by relationships with the smartphone.

Social and familial connections: "It's disrespectful. People look at the phone instead of face-to-face", said Lizzy. Fanny said: "Some people don't know how to converse [...] You need relationships with people." Bruria explained: "everyone is immersed in their smartphones, they don't lift their eyes to see the sun or the people around them. It creates separation and autism." Shulamit observed: "people are not connected to their environments: the chin is lowered; their small incurious eyes search for something.' Miriam wrote: "people lose the ability to connect in person with their surroundings, they concentrate on the smartphone and the many ways to make internet connections." Tehila and Nechama (Ultra-Orthodox) thus described their encounters with smartphone users: "I went to the park with my five children, every one of the kids there gets ten times more attention than the secular girl whose mother has one interesting smartphone" (Tehila), and "I see [non-Ultra-Orthodox] workers in my workplace and go crazy. They are half with me, half with the smartphone" (Nechama). Their observations are in keeping with empirical studies on how the use of mobile devices has changed social interactions (e.g., Ahn and Jung 2016). As we saw in the Ultra-Orthodox wedding example discussed above, the distinction Sari made between connectivity with people who need her, especially husband and children, and entertainment, defined the meaning of the device for her - she can answer phone calls; she can't get pictures or news updates - and her ability to prioritize family and friends over "the world."

Self-connection: Dina observed: "people are not available in the space and time in which they are while they are texting and surfing" (italics added). And Esther wrote: "people don't listen to themselves, don't think, ask or pray (italics added)." Tova diagnosed: "people have lost the soul tranquility that they had. Adults sit on the bus texting, playing cards. The smartphone steals our self-quiet quality time (italics added)." Some women used medical terms: "it's an 
addiction, he can't be without the device that distracts him from life for even a moment. People are afraid of being alone and escape from themselves,' (Pnina) (italics added). "People need to be with themselves. I see the bus passengers talking, surfing, typing - all on Facebook. Its obsessive" (Giti) (italics added). I attempted to understand why only Ultra-Orthodox women and none of the Amish women referenced self-connections. It may due to the Amish ethic of humility and submission, where community identity has precedence over individual identity. Fishman (1987, 1988) found that Amish education contributes to the reduction of emphasis on the self, e.g., through training to write in first-person-plural, which is different than the usual composition of third-personsingular. Another possible reason might be that UltraOrthodox women work outside the home, and sometimes outside the community, which, along with their extensive use of public transport gives them many more opportunities to observe smartphone users than Amish women, who more often stay at home and mostly travel by horse-and-buggy.

They felt that the real danger of the smartphone lies in its ability to enter our deepest private places our bodies and souls and create a real attachment with them: "People stick to the phone [...] missing out on their life," said Lavina (italics added). "They hang on to the smartphone all the time," observed Barbara (italics added). "Their halo [of smartphone users] would slip because it doesn't stick," explained Beki-Lyn (italics added). While the Amish women used the terms they or their, the Ultra-Orthodox used you. "If you have a smartphone you have a stain. It means that you are spoiled," wrote Miriam (italics added). "You connect anytime to the bad things on the internet," wrote Tehila (italics added). "You put yourself in bad places," reminded Nechama (italics added). Giti even used the term $m y$ : "I don't want $m y$ soul to enter this dirt" (italics added). Some UltraOrthodox used metaphors from the realms of medicine and the body: "the smartphone is like oxygen, entering the body all the time," (italics added) wrote Hindi, and Haya said: "the danger goes with the DNA everywhere, like a weapon in the pocket." Malka analyzed: "I see my [non-Ultra-Orthodox] pupils. The smartphone creates a dystrophy of the brain." (italics added)

As discussed in the literature review, separationindividuation theory delineates the phases through which infants, toddlers, children, and adults, progress when moving from dependence to independence, and achieving autonomous self-individuation (Mahler
1972; Mahler and McDevitt 1982). People today can fall asleep in front of the television, and work with their laptops and tablets almost anywhere. They might feel attachment to these devices, but they do not usually hold them all the time, and do not fall asleep with them. In terms of our development, the smartphone, through its function as a transitional object, reverts us towards infancy, as we need to hold it close in order to achieve relaxation. As Winnicott $(1953,89)$ observes, one of the most important things for the infant's development is the "infant's capacity to recognize the object as 'not-me' ... the intermediate area of experience, between the thumb and the teddy bear ... objects that are not part of the infant's body yet are not fully recognized as belonging to external reality" (Winnicott 1953, 89). With this understanding, we should think again about how people feel identify with their smartphones (Tojib, Tojib, Tsarenko, and Sembada 2015). Consequently, I think that the smartphone represents backward movement, from people capable of managing relationships with technology [e.g., cellphone as a transitional object (Ribak 2009; Rosenberg 2014), and ultimately to people being enmeshed with a plastic/metal device, a smartphone, without the ability to recognize that this is "not me." More than simply an extension of the person (McLuhan 1964), the smartphone envelops its users, dominating and controlling them (Casetti and Sampietro 2012; Farman 2012; Snickars and Vonderau 2012). Both the Amish and Ultra-Orthodox women understand this process without their own participation. It is their different understanding of the boundaries between the public and the private that enable them to do so. Their special and unique location as outsiders enables them to develop insights on the phenomenon, and to simultaneously see the changes in both the systems of connections and separations.

Their different perceptions also prompt me to revisit context collapse theory. Both communities have terms for anybody outside of their own group, the Amish call them "English" (although they could be Hindu) and the Ultra-Orthodox call them "not from us." Their concerns with smartphones as channels of worldly content arise from this distinction, a defining feature of their communities. However, it seems to me that the more interesting public/private distinction occurs within their own communities - the community itself as the public, and the person or family as the private.

Goffman (1956) noted that people's self-presentation and impression management performances occur in many locations and regions. He defined "region" as 
"any place that is bounded to some degree by barriers to perception," with the key performance taking place in the "front region," or onstage, in accordance with certain standards, including decorous behavior (66). This performance, he explained, may be motivated by the desire to impress the audience or avoid sanctions. The backstage is a hidden space "where the impression fostered by the performance is knowingly contradicted as a matter of course" (69).

Goffman understood that the need for maintaining an impression demands that the performer act with high moral standards. Life in communities such as the Amish and Ultra-Orthodox, demands a very high moral degree of obedience from its members, and almost unlimited acting by the individual, if this term can even be said to exist among them. I argue that an important aspect of these communities is a fusion of social control that creates "collective pressure to signal loyalty" (Douglas 2005, 2), with the emphasis on demonstrating virtue and strict conduct, which, in turn, provides prestige and appreciation (Friedman 1993; Kraybill, Johnson-Weiner, and Nolt 2013; Soloveitchik 1994). In effect, almost all daily practices are subject to community control (Douglas 1970, 1992). Since many of these practices, religious and nonreligious alike, take place in the home, this "backstage" space, is not private, but becomes a central space for social control.

In the world of smartphone, people take digital actions with the "invisible audience" in mind (Marwick 2012; Marwick and boyd 2014). The Amish and the Ultra-Orthodox, on the other hand, have the gaze of a "real", not technologically mediated, audience - their close-knit community. They recognize that their boundary management is much more difficult than in other societies, because their privacy is much less important than preservation of social surveillance. Therefore, while smartphone users, "the English", in Amish terms, deal with privacy issues by focusing on the boundaries between the public and private, these communities in contrast, as part of collectivist groups, do not really bother themselves with these public/private questions within the community, rather with the important boundaries between oneself, one's body, and one's soul.

\section{Conclusions}

While Amish and Ultra-Orthodox women differ in cellphone use - Amish do not own and mostly do not use cellphones, the Ultra-Orthodox own and use kosher cellphones, they are similar in their nonuse of smartphones. Both view smartphones as undermining social relations and community by opening access to impure content and distracting users away from friends and family. However, they differ in how they arrive at this understanding.

In the case of radio and newspapers, the primary fear among the Amish is the medium itself, while among the Ultra-Orthodox it is the message. However, in the case of smartphones, both believe that the medium itself is more dangerous than the message. They see it as overpowering that which is human, and blurring social boundaries while undermining the old order.

Apparatgeist theory enables us to deepen our understanding about the usage and perceptions of cellphones and smartphones by Amish and UltraOrthodox women. Both see the cellphone as a functional tool, whose design is similar to the landline phone. Both also focus on their communal values. The Amish oppose the cellphone because they think that it harms family and community commitments. The Ultra-Orthodox, however, focus on a woman's availability to her family (and vice versa), particularly while working or attending social events. For them, once the cellphone is limited in is capabilities and made kosher, it is fine. On the other hand, UltraOrthodox view the smartphone, which affords unlimited opportunities to connect to the outside world, very differently - they see the device itself to be dangerous, much like the Amish. In other words, drawing on Meyrowitz (1985), while the Amish feel the context collapse even with the cellphone, as it brings the outside world into the home, the Ultra-Orthodox are comfortable with cellphones, seeing it as bringing work, family, and community together, by increasing access to individuals away for work and social reasons. On the other hand, for both Amish and UltraOrthodox, the smartphone is different because they see it as a device with a "life of its own" that undermines the core values of both groups. Both groups keep a strictly sensitive balance between utility and values - when values outweigh utility, values win. Neither the Amish nor the Ultra-Orthodox want long or short distance connections created by the medium that might change "our expectations of one another" (Ling 2012, xi). They prefer real and close relationships to constant "connections" creating [false] feelings of being together, when in reality people "alone together" (Turkle 2012). While the Apparatgeist and context collapse theories have separately provided different insights, the finds of this study point to the intersection between them, and the developmental psychology theories (Bowlby 1969, 1979; Mahler 1972; Mahler and McDevitt 1982; Winnicott 1953), which is a contribution of this article. 
The telephone was the first electronic medium that entered the home and changed the ways private people and families were separated from public, political or communal spaces (Marvin 1988). Indeed, if the telephone disrupted these limits, smartphones have destroyed them. The Amish and Ultra-Orthodox understand that the dangers go beyond the blurring of the boundaries between private and public. They see this technology as leading humanity hurtling toward a new multi-leveled "context collapse" (boyd 2008; Meyrowitz 1985). They see it as critically subverting the limits that used to exist between humans and technology, making these devices increasingly an integral part of the human being - way beyond attachment between the person and the device (Farman 2012), transitional object (Winnicott 1953), or an extension of person (McLuhan 1964). My understanding of the responses of the Amish and UltraOrthodox women is that smartphone users cannot complete the separation-individuation process, when they still hold the smartphone as transitional object, feeling real stress without it. In this sense, compared to smartphone users, enmeshed and merged with the smartphone, these women are adults, looking from the outside at the users' dependency on a small device.

The issues addressed here need to be investigated with larger samples that include Amish and UltraOrthodox Jewish men. Further studies on the suggested intersection between the Apparatgeist and the multiple levels of "context collapse," could provide deeper insights into the relationship between humans and technology, which could shed light on crucial questions about our close relationships with wearable devices (Banerjee, Hemphill, and Longstreet 2018).

\section{Notes}

1. Tojib, Tojib, Tsarenko, and Sembada (2015) define the attachment, as "the extent to which an individual uses an object to develop and maintain a cognitive structure of self" (156).

2. Recent studies have shown that there is need to go beyond user-nonuser binaries and develop dynamic conceptual frameworks for understanding the broad continuum of use and non-use (Lutz and Hoffmann 2017; Ribak and Rosenthal 2015; Wyche and Baumer 2017). Some researchers have also argued that internet non-use could enable empowerment and agency among non-users (Hakkarainen 2012; Neriya-Ben Shahar 2017a; Portwood-Stacer 2012; Selwyn 2003; Reisdorf and Groselj 2017).
3. At first glance, the segregationist patterns adopted by the Amish and Ultra-Orthodox would seem congruent with the notion of enclave culture (Almond, Appleby, and Sivan 2003; Ammerman 1987, 2007; Douglas 1966, 1970, 2005; Glick Schiller 2005; Guzmen-Carmeli and Sharabani 2014; Inbari 2016; Levy 1999; Marty and Appleby 1991; Siu 2007; Turner 2007).

\section{Acknowledgments}

I would like to thank the editor, Prof. Sawhney, and anonymous reviewers for their constructive suggestions and comments, and Rena Bannett for her skillful editing. This article was written with the generous support of a Fulbright Foundation post-doctoral grant, Hadassah-Brandeis Institute's scholar-in-residence research grant, The Young Center for Anabaptist and Pietist Studies' Snowden Fellowship and a Memorial Foundation research grant. I would like to thank the Sapir Academic College for its help and support in financing the English editing process of this article. My thanks to the Stemmer family, my generous hosts in Sharon, MA, whose hospitality enabled me the best conditions to write quietly. This article is devoted to you.

\section{References}

Adkins, T. 2012. Researching the "un-digital" Amish community: Methodological and ethical reconsiderations for human subjects' research. Community Literacy Journal 6 (1):39-53. doi: 10.1353/clj.2012.0014.

Ahn, J., and Y. Jung. 2016. The common sense of dependence on smartphone: A comparison between digital natives and digital immigrants. New Media \& Society 18 (7):1236-56. doi: 10.1177/1461444814554902.

Almond, G. A., S. R. Appelby, and E. Sivan. 2003. Strong religion: The rise of fundamentalisms around the world. Chicago: University of Chicago Press.

Ammerman, N. T. 1987. Bible believers: Fundamentalists in the modern world. New Brunswick, NJ: Rutgers University Press.

Ammerman, N. T. 2007. Everyday religion. New York: Oxford University Press.

Banerjee, S., T. Hemphill, and P. Longstreet. 2018. Wearable devices and healthcare: Data sharing and privacy. The Information Society 34 (1):49-57. doi: 10.1080/ 01972243.2017.1391912.

Barzilai-Nahon, K., and G. Barzilai. 2005. Cultured technology: The internet and religious fundamentalism. The Information Society 21 (1):25-40. doi: 10.1080/ 01972240590895892.

Blondheim, M., and H. Rosenberg. 2016. The handshake of new media and theology: ICTs as religious constructs, metaphors and experiences. New Media \& Society 19 (1): 43-51. doi: 10.1177/1461444816649915.

Bowlby, J. 1969. Attachment and loss, Vol. 1. New York: Basic Books. doi: 10.1093/sw/26.4.355.

Bowlby, J. 1979. The making and breaking of affectional bonds. London: Routledge. 
Boyd, D. 2002. Faceted id/entity: Managing representation in a digital world. Master's Thesis, Massachusetts Institute of Technology.

Boyd, D. 2008. Taken out of context: American teen sociality in networked publics. Doctoral Dissertation. University of California, Berkeley.

Boyd, D. 2011. Social network sites as networked publics: Affordances, dynamics, and implications. In A Networked Self: Identity, Community, and Culture on Social Network Sites, ed. Z. Papacharissi, 39-58. New York: Routledge.

Büchi, M., N. Just, and M. Latzer. 2016. Modeling the second-level digital divide: A five-country study of social differences in internet use. New Media \& Society 18 (11): 2703-922. doi: 10.1177/1461444815604154.

Cahaner, L., and H. Zicherman. 2012. Modern ultra-orthodoxy: The emergence of the Haredi middle class in Israel [Hebrew]. Jerusalem: The Israel Democracy Institute.

Cahaner, L., G. Malach, and M. Choshen. 2017. The yearbook of ultra-orthodox society in Israel [Hebrew]. Jerusalem: The Israel Democracy Institute.

Campbell, H. 2007. What hath God wrought?" Considering how religious communities culture (or kosher) the cell phone. Continuum 21 (2):191-203. doi: 10.1080/ 10304310701269040.

Campbell, H. 2010. When religion meets new media. London: Routledge.

Campbell, H. 2013. Religion and the internet: A microcosm for studying Internet trends and implications. New Media \& Society 15 (5):680-94. doi: 10.1177/1461444812462848.

Campbell, H. ed. 2015. Digital Judaism: Jewish Negotiations with Digital Media and Culture. New York: Routledge.

Campbell, H., and A. C. La Pastina. 2010. How the iPhone became divine: New media, religion and the intertextual circulation of meaning. New Media \& Society 12 (7): 1191-207. doi: 10.1177/1461444810362204.

Caplan, K. 2007. The internal popular discourse in Israeli Haredi Society [Hebrew]. Jerusalem: Zalman Shazar

Caplan, K. and N. Stadler, Eds. 2012. From survival to consolidation: Changes in Israeli Haredi society and its scholarly study [Hebrew]. Jerusalem: Van Leer Ins.

Casetti, F., and S. Sampietro. 2012. Into the iPhone. In Moving data: The iPhone and the future of media, eds. P. Snickars and P. Vonderau, 19-32. New York: Columbia University Press.

Cohen, A. A., D. Lemish, and A. Schejter. 2008. The wonder phone in the land of miracles. New York: Hampton Press.

Cooper, T. W. 2006. Of script and scriptures: Why plain people perpetuate a media fast. The Journal of American Culture 29 (2):139-53. doi: 10.1111/j.1542-734X.2006. 00325.x.

David, Y., and C. Baden. 2018. Reframing community boundaries: The erosive power of new media spaces in authoritarian societies. Information, Communication \& Society. 1-18. doi: 10.1080/1369118X.2018.1486869.

Davidman, L. 1991. Tradition in a rootless world: Women turn to orthodox Judaism. Berkeley, CA: University of California Press.

Deutsch, N. 2009. The forbidden fork, the cell phone holocaust, and other Haredi encounters with technology. Contemporary Jewry 29 (1):3-19. doi: 10.1007/s12397008-9002-7.
Donovan, P. 1990. Neutrality in religious studies. Religious Studies 26 (1):103-16. doi: 10.1017/S0034412500020230.

Douglas, M. 1966. Purity and danger: An analysis of concepts of pollution and taboo. London: Routledge \& Kegan Paul.

Douglas, M. 1970. Natural symbols: Explorations in cosmology. London: Routledge.

Douglas, M. 2005. A history of grid and group cultural theory. Paper presented at the University of Toronto. Available at: http://projects.chass.utoronto.ca/semiotics/ cyber/douglas1.pdf. (accessed oSeptember 22, 2019).

El-Or, T. 1994. Educated and ignorant: Ultra-orthodox Jewish women and their world. Boulder, CO: Lynne Rienner.

Ems, L. 2015. Exploring ethnographic techniques for ICT non-use research: An Amish case study. First Monday 20 (11):8. https://journals.uic.edu/ojs/index.php/fm/article/ view/6312/5139 (accessed September 22, 2019).

Fader, A. 2013. Nonliberal Jewish women's audiocassette lectures in Brooklyn: A crisis of faith and the morality of media. American Anthropologist 115 (1):72-84. doi: 10. 1111/j.1548-1433.2012.01536.x.

Farman, J. 2012. Mobile interface theory: Embodied space and locative media. New York: Routledge.

Firth, R. 1996. Religion: A humanist interpretation. New York: Routledge.

Fishman, A. R. 1987. Literacy and cultural context: A lesson from the Amish. Language Arts 64 (8):842-54.

Fishman, A.R. 1988. Amish literacy: What and how it means. Portsmouth, NH: Heinemann.

Fiske, J. 1986. Television: Polysemy and popularity. Critical Studies in Mass Communication 3 (2):200-16. doi: 10. 1080/15295039609366644.

Friedman, I. 2011. Measurement and estimates of the population of ultra-orthodox Jews [Hebrew]. Jerusalem: Central Bureau of Statistics.

Friedman, M. 1991. Haredi society: Sources, trends and processes [Hebrew]. Jerusalem: Jerusalem Institute for Israel Studies.

Friedman, M. 1993. The market model and religious radicalism. In Jewish Fundamentalism in Comparative Perspective: Religion, Ideology and the Crisis of Modernity, ed. L. J. Silberstein, 192-215. New York: New York University Press.

Geertz, C. 1983. Local knowledge: Further essays in interpretive anthropology. New York: Basic Books.

Ginsburg, F. 1991. Indigenous media: Faustian contract or global village?. Cultural Anthropology 6 (1):92-112. doi: 10.1525/can.1991.6.1.02a00040.

Glick Schiller, N. 2005. Transnational urbanism as a way of life: A research topic not a metaphor. City \& Society 17 (1):49-64. doi: 10.1525/city.2005.17.1.49.

Goffman, E. 1956. The presentation of self in everyday life. Edinburgh, UK: University of Edinburgh.

Golan, O., and N. Mishol-Shauli. 2018. Fundamentalist web journalism: Walking a fine line between religious ultraorthodoxy and the new media ethos. European Journal of Communication 33 (3):304-20. doi: 10.1177/ 0267323118763928.

Graybill, B. E. 2009. Amish women, business sense: Old order women entrepreneurs in the Lancaster county, 
Pennsylvania. Tourist Marketplace. Doctoral Dissertation, University of Maryland.

Guzmen-Carmeli, Shlomo, and Asaf Sharabi. 2014. The holy contract: The social contract of the Toldos Aharon Hasidic group. Social Compass 61 (3):290-309. doi: 10. $1177 / 0037768614535697$.

Hakkarainen, P. 2012. No good for shoveling snow and carrying firewood": Social representations of computers and the internet by elderly Finnish non-users. New Media \& Society 14 (7):1198-215. doi: 10.1177/1461444812442663.

Hargittai, E. 2004. Internet access and use in context. New Media \& Society 6 (1):137-43. doi: 10.1177/ 1461444804042310.

Hargittai, E., and G. Walejko. 2008. The participation divide. Information, Communication \& Society 11 (2): 239-56. doi: 10.1080/13691180801946150.

Hess, M. E. 2013. Digital storytelling: Empowering feminist and womanist faith formation with young women. In Media, religion and gender: Key issues and new challenges. ed. M. Lovheim, 336-62. London: Routledge.

Hobson, D. 1981. Housewives and the mass media. In Culture, Media, Language: Working Papers in the Cultural Studies 1972-79, eds. S. Hall, D. Hobson, A. Lowe, and P. Willis, 105-14. London: Hutchinson.

Hobson, D. 1990. Women, audiences and the workplace. In Television and Women's Culture: The Politics of the Popular, ed. M. E. Brown, 61-74. Thousand Oaks, CA: Sage.

Hoffner, C. A., S. Lee, and S. J. Park. 2016. I miss my mobile phone!": Self-expansion via mobile phone and responses to phone loss. New Media \& Society 18 (11): 2452-68. doi: 10.1177/1461444815592665.

Hostetler, J. A. 1993. Amish society. Baltimore, MD: Johns Hopkins University Press.

Hostetler, J. A. 1996. The Amish as a redemptive community. In The Amish: Origin and characteristics, ed. L. Hege and C. Wiebe, 346-55. Ingersheim, France: Association Franc,Aise D'Histoire. AnabaptisteMennonite.

Hurst, C. E., and D. L. McConnell. 2010. An Amish paradox: Diversity and change in the world's largest Amish Community. Baltimore, MD: Johns Hopkins University Press.

Inbari, M. 2016. Jewish radical ultra-orthodoxy confronts modernity, zionism and women's equality. New York: Cambridge University Press.

Johnson-Weiner, K. 2001. The role of women in old order Amish, Beachy Amish and fellowship churches. Mennonite Quarterly Review 75 (2):231-56.

Johnson-Weiner, K. 2014. Technological diversity and cultural change among contemporary Amish groups. Mennonite Quarterly Review 88 (1):5-23.

Jolly, N. 2014. Amish femininity: New lessons from the old order. Journal of Motherhood Initiative 5 (2):75-89.

Jolly, N. P. 2007. Public culture. Private Birth: Social Pattern of Amish Domestic Space. Doctoral Dissertation, Pennsylvania State University.

Katz, J. E., and M.A. Aakhus. eds. 2004. Perpetual contact: Mobile communication, private talk, public performance. Cambridge, UK: Cambridge University Press.

Kraybill, D. B. 1989. The riddle of Amish culture. Baltimore, MD: Johns Hopkins University Press.
Kraybill, D. B. 2008. Amish informants: Mediating humility and publicity. In The Amish and the Media, eds. D. Zimmerman Umble and D. Weaver-Zercher, 161-80. Baltimore, MD: Johns Hopkins University Press.

Kraybill, D. B., K. M. Johnson-Weiner, and S. M. Nolt. 2013. The Amish. Baltimore, MD: Johns Hopkins University Press.

Lee, R. M. 1993. Doing research in sensitive topics. London: Sage.

Leonardi, P. M. 2003. Problematizing "new media": Culturally based perceptions of cell phones, computers, and the Internet among United States Latinos. Critical Studies in Media Communication 20 (2):160-79. doi: 10. 1080/07393180302778.

Leonardi, P. M. 2009. Why do people reject new technologies and stymie organizational changes of which they are in favor? Exploring misalignments between social interactions and materiality. Human Communication Research 35 (3):407-41. doi: 10.1111/j.1468-2958.2009.01357.x.

Lev-On, A., and R. Neriya-Ben Shahar. 2012. To browse, or not to browse? Third person effect among UltraOrthodox Jewish women, in regards to the perceived danger of the internet. In New Media and Intercultural Communication: Identity, Community, and Politics, eds. P. H. Cheong, J. N. Martin, and L. P. Macfadyen, 223-6. New York: Peter Lang.

Levy, A. 1999. Playing for control of distance: Card games between Jews and Muslims on a Casablancan beach. American Ethnologist 26 (3):632-53. doi: 10.1525/ae.1999. 26.3.632.

Lim, S. S., and C. Soon. 2010. The influence of social and cultural factors on mothers' domestication of household ICTs: Experiences of Chinese and Korean women. Telematics and Informatics 27 (3):205-16. doi: 10.1016/j. tele.2009.07.001.

Ling, R. 2012. Taken for grantedness: The embedding of mobile communication into society. Cambridge, MA: MIT Press.

Livingstone, S. 1990. Making sense of television: The psychology of audience interpretation. Oxford: Pergamon Press.

Livingstone, S. 1992. The meaning of domestic technologies: A personal construct analysis of familial gender relations. In Consuming Technologies: Media and Information in Domestic Spaces, eds. R. Silverstone and E. Hirsch, 113-30. London: Routledge.

Livingstone, S. 2003. On the challenges of cross-national comparative media research. European Journal of Communication 18 (4):477-500. doi: 10.1177/ 0267323103184003.

Livio, O., and K. Tenenboim Weinblatt. 2007. Discursive legitimation of a controversial technology: UltraOrthodox Jewish women in Israel and the internet. The Communication Review 10 (1):29-56. doi: 10.1080/ 10714420601168467.

Lookout Inc. 2012. Mobile mindset study. https://www. mediaenmaatschappij.nl/images/artikelen/PDF/Mobile\% 20Mindset,\%20Juni\%202012.pdf (accessed September 22, 2019).

Lovheim, M. 2013a. Introduction: Gender - a blind spot in media, religion and culture?. In Media, Religion and gender: Key issues and new challenges, ed. M. Lovheim, 15-42. London: Routledge. 
Lovheim, M. 2013b. Media and religion through the lens of feminist and gender theory. In Media, Religion and gender: Key issues and new challenges, ed. M. Lovheim, 43-76. London: Routledge.

Lovheim, M. 2013c. Media, religion and gender: Key insights and future challenges. In Media, religion and gender: Key issues and new challenges, ed. M. Lovheim, 363-86. London: Routledge.

Lutz, C., and C. P. Hoffmann. 2017. The dark side of online participation: Exploring non-, passive and negative participation. Information, Communication \& Society 20 (6): 876-97. doi: 10.1080/1369118X.2017.1293129.

Mahler, M. S. 1972. On the first three subphases of the separation-individuation process. International Journal of Psycho-Analysis 53:333-8.

Mahler, M. S., and J. McDevitt. 1982. Thoughts on the emergence of a sense of self, with a particular emphasis on the body self. Journal of the American Psychoanalytic Association 30 (4):827-48. doi: 10.1177/0003065182 03000401.

Marty, M., and S. Appleby, eds. 1991. Fundamentalisms observed. Chicago: University of Chicago Press.

Marvin, C. 1988. When old technologies were new. Oxford: Oxford University Press. doi: 10.1086/ahr/94.3.714.

Marwick, A. E., and d Boyd. 2014. Networked privacy: How teenagers negotiate context in social media. New Media \& Society 16 (7):1051-67. doi: 10.1177/14614448145 43995.

Marwick, A.E. 2012. The public domain: Surveillance in everyday life. Surveillance \& Society 9 (4):378-93. doi: 10. 24908/ss.v9i4.4342.

McCutcheon, R.T. ed. 2005. The insider/outsider problem in the study of religion: A reader. New York: Continuum.

McLuhan, M. 1964. Understanding media: The extensions of man. New York: Mcgraw-Hill.

Meyrowitz, J. 1985. No sense of place: The impact of electronic media on social behavior. New York: Oxford University Press.

Morley, D. 1992. Television, audiences and cultural studies. London: Routledge.

Morley, D. 1998. Domestic relations: The framework of family viewing in Great Britain. In Approaches to Audience: A Reader, eds. R. Dickinson, R. Harindranath, and O. Linné, 233-44. London: Arnold.

Nafus, D., and K. Tracy. 2004. Mobile phone consumption and concepts of personhood. In Perpetual Contact: Mobile Communication, Private Talk, Public Performance., eds. J. E. Katz and M.A. Aakhus, 206-22. Cambridge, UK: Cambridge University Press.

Neriya-Ben Shahar, R. 2008. Haredi (Ultra-Orthodox) women and mass media in Israel: Exposure patterns and reading strategies [Hebrew]. Doctoral Dissertation, Hebrew University, Jerusalem.

Neriya-Ben Shahar, R. 2009. The learners' society: Continuity and change in characteristics of education and employment among Ultra-Orthodox (Haredi) women. Sociological Papers 14:1-15.

Neriya-Ben Shahar, R. 2012. Some outlooks are not our own, but if I happen to see one I'll look at it from time to time": Self-definition of Haredi (Ultra-Orthodox) women according to patterns of exposure to the Haredi press [Hebrew]. In From Survival to Consolidation:
Changes in Israeli Haredi Society and Its Scholarly Study, eds. K. Caplan and N. Stadler, 137-61. Jerusalem: Van Leer Jerusalem Institute.

Neriya-Ben Shahar, R. 2017. The medium is the danger: Discourse about television among Amish and UltraOrthodox (Haredi) women. Journal of Media and Religion 16 (1):27-38. doi: 10.1080/15348423.2017. 1274590.

Neriya-Ben Shahar, R. 2017a. Negotiating agency: Amish and Ultra-Orthodox women's responses to new media. New Media \& Society 19 (1):81-95. doi: 10.1177/ 1461444816649920.

Neriya-Ben Shahar, R., and A. Lev-On. 2011. Gender, religion, and new media: Attitudes and behaviours related to the internet among Ultra-Orthodox women employed in computerized environments. International Journal of Communication 5:875-95.

Neuberger, B. 2011. The Amish, the rule of law and freedom of religion: The culture of compromise in American democracy. Democratic Culture 12:115-40.

Neuberger, B., and K. M. Tamam. 2014. The image of the Amish in the New York Times versus the image of the Haredim in Haaretz (1980-2010). Conflict and Communication Online 13 (1):1-17.

Nolt, S. M. 2015. You hold the whole world in your hand": Cell phones and discernment in Amish churches. Vision: A Journal for Church and Theology 16 (2):27-37.

Nolt, S. M. 2016. The Amish: A concise introduction. Baltimore, MD: Johns Hopkins University Press.

Pew Research Center. 2013. A portrait of Jewish Americans. https://www.pewforum.org/2013/10/01/jewish-americanbeliefs-attitudes-culture-survey/(accessed September 22, 2019)

Pinch, T., and W. B. Bijker. 1984. The social construction of facts and artefacts: Or how the sociology of science and the sociology of technology might benefit each other. Social Studies of Science 14 (3):399-441. doi: 10.1177/ 030631284014003004.

Portwood-Stacer, L. 2012. Media refusal and conspicuous non-consumption: The performative and political dimensions of Facebook abstention. New Media \& Society 15 (7):1041-57. doi: 10.1177/1461444812465139.

Press, A. L. 1991. Women watching television: Gender, class, and generation in the American Television experience. Philadelphia, PA: University of Pennsylvania Press.

Rashi, T. 2013. The kosher cell phone in ultra-orthodox society: A technological ghetto within the global village? In Digital religion: Understanding religious practice in new media Worlds, ed. H. Campbell, 173-81. New York: Routledge.

Reisdorf, B. C., and D. Groselj. 2017. Internet (non-) use types and motivational access: Implications for digital inequalities research. New Media \& Society 19 (8): 1157-76. doi: 10.1177/1461444815621539.

Ribak, R. 2009. Remote control, umbilical cord and beyond: The mobile phone as a transitional object. British Journal of Developmental Psychology 27 (1):183-96. doi: 10.1348/ $026151008 X 388413$.

Ribak, R., and M. Rosenthal. 2015. Smartphone resistance as media ambivalence. First Monday 20 (11). https://journals.uic.edu/ojs/index.php/fm/article/view/6307/5136 (accessed September 22, 2019). 
Rier, D. A., A. Schwartzbaum, and C. Heller. 2008. Methodological issues in studying an insular, traditional population: A women's health survey among Israeli Haredi (ultra-Orthodox) Jews. Women \& Health 48 (4): 363-81. doi: 10.1080/03630240802575054.

Rosenberg, H. 2014. Backpacking experience and the mobile phone [Hebrew]. Media Frames 13:39-92.

Rosenberg, H., and T. Rashi. 2015. Pashkevillim in campaigns against new media: What can pashkevillim accomplish that newspapers cannot?. In Digital Judaism, ed. H. Campbell, 161-82. London: Routledge.

Rosenberg, H., M. Blondheim, and E. Katz. 2016. The wallkeepers": Social enclaves, social control and the kosher cellphone campaign in Jewish ultra-orthodox society [Hebrew]. Israeli Sociology 17 (2):116-37.

Said, E. W. 1979. Orientalism. New York: Vintage Books

Schmidt, K. D., and S. D. Reschly. 2000. A women's history for Anabaptist tradition: A framework of possibilities, possibly changing the framework. Journal of Mennonites Study 18:29-46.

Schmidt, K. D., D. Zimmerman-Umble, and S. D. Reschly. 2002. Strangers at home: Amish and mennonites women in history. Baltimore, MD: Johns Hopkins University Press.

Selwyn, N. 2003. Apart from technology: Understanding people's non-use of information and communication technologies in everyday life. Technology in Society 25 (1):99-116. doi: 10.1016/S0160-791X(02)00062-3.

Silverstone, R. 1991. From audiences to consumers: The household and the consumption of communication and information technologies. European Journal of Communication 6 (2):135-54. doi: $10.1177 /$ 0267323191006002002.

Silverstone, R., E. Hirsch, and D. Morley. 2002. Information and communication technologies and the moral economy of the household. In Consuming technologies: Media and information in domestic spaces, eds. R. Silverstone and E. Hirsch, 16-31. London: Routledge

Siu, H. F. 2007. Grounding displacement: Uncivil urban spaces in post reform South China. American Ethnologist 34 (2):329-50. doi: 10.1525/ae.2007.34.2.329.

Sivan, E., and K. Caplan. 2003. eds. Israeli Haredim: Integration without Assimilation? [Hebrew] Jerusalem: Jerusalem Institute for Israel Studies.

Snickars, P., and P. Vonderau. 2012. Introduction. In moving data: The iPhone and the future of media, eds. P. Snickars and P. Vonderau, 1-17. New York: Columbia University Press.

Soloveitchik, H. 1994. Rupture and reconstruction: The transformation of contemporary Orthodoxy. Tradition 28 (4):64-130.

Spinner, J. 1994. The boundaries of citizenship: Race, ethnicity and nationality in the liberal state. Baltimore, MD: Johns Hopkins University Press.

Stout, D. A. 2001. Beyond culture wars: An introduction to the study of religion and popular culture. In Religion and popular culture: Studies on the interaction of worldviews, eds. D. A. Stout and J. M. Buddenbaum, 3-18. Ames, IA: Iowa State University Press.

Stout, D. A. 2012. Media and religion: Foundation of an emerging field. New York: Routledge.

Strauss, A., and J. M. Corbin. 1990. Basics of qualitative research. Thousand Oaks, CA: Sage.

Tacchi, J., R. Kitner, and K. Crawford. 2012. Meaningful mobility: Gender, development and mobile phones. Feminist Media Studies 12 (4):528-37. doi: 10.1080/ 14680777.2012.741869.

Tojib, T., S. D. Tojib, Y. Tsarenko, and A. Y. Sembada. 2015. The facilitating role of smartphones in increasing use of value-added mobile services. New Media \& Society 17 (8):1220-40. doi: 10.1177/1461444814522951.

Turkle, S. 2008. Always-on/always-on-you: The tethered self. In Handbook of Mobile Communication Studies, ed. J. E. Katz, 121-38. Cambridge, MA: MIT Press.

Turkle, S. 2012. Alone together: Why we expect more from technology and less from each other. New York: Basic Books.

Turner, B. S. 2007. Managing religions: State responses to religious diversity. Contemporary Islam 1 (2):123-37. doi: 10.1007/s11562-007-0011-1.

van Deursen, A., and A. G. M. van Dijk. 2015. Toward a multifaceted model of internet access for understanding digital divides: An empirical investigation. The Information Society 31 (5):379-91. doi: 10.1080/01972243. 2015.1069770.

van Deursen, A., and J. van Dijk. 2014. The digital divide shifts to differences in usage. New Media \& Society 16 (3):507-26. doi: 10.1177/1461444813487959.

Van Ness, S. 1995. Ohio Amish women in the vanguard of a language change: Pennsylvania German in Ohio. American Speech 70 (1):69-80. doi: 10.2307/455871.

Winnicott, D.W. 1953. Transitional objects and transitional phenomena: A study of the first not-me possession. The International Journal of Psychoanalysis 34 (2):89-97.

Wyatt, S., F. Henwood, A. Hart, and J. Smith. 2005. Digital divide, health information and everyday life. New Media \& Society 7 (2):199-218. doi: 10.1177/1461444805050747.

Wyche, S., and E. Baumer. 2017. Imagined Facebook: An exploratory study of non-users' perceptions of social media in rural Zambia. New Media \& Society 19 (7): 1092-108. doi: 10.1177/1461444815625948.

Young Center. 2019. Amish Population Profile, 2018. http:// groups.etown.edu/amishstudies/statistics/population-2018/ (accessed August 29, 2019).

Zimmerman Umble, D. 1992. The Amish and the telephone: Resistance and reconstruction. In Consuming Technologies: Media and Information in Domestic Spaces, eds. R. Silverstone and E. Hirsh, 183-94. London: Routledge.

Zimmerman Umble, D. 2003. Sinful network or divine service: Competing meanings of the telephone in Amish country. In New Media, 1740-1915, eds. L. Gitelman and G. B. Oingree, 139-56. Cambridge, MA: MIT Press. 